\title{
A Conceptual Framework to Study the Implementation of Clinical Decision Support Systems (BEAR): Literature Review and Concept Mapping
}

Jhon Camacho ${ }^{1,2}$, BEng, MSc; Manuela Zanoletti-Mannello ${ }^{3}$, MD; Zach Landis-Lewis ${ }^{4}$, MLIS, PhD; Sandra L Kane-Gill ${ }^{5}$, MS, PharmD, FCCP, FCCM; Richard D Boyce ${ }^{1}$, PhD

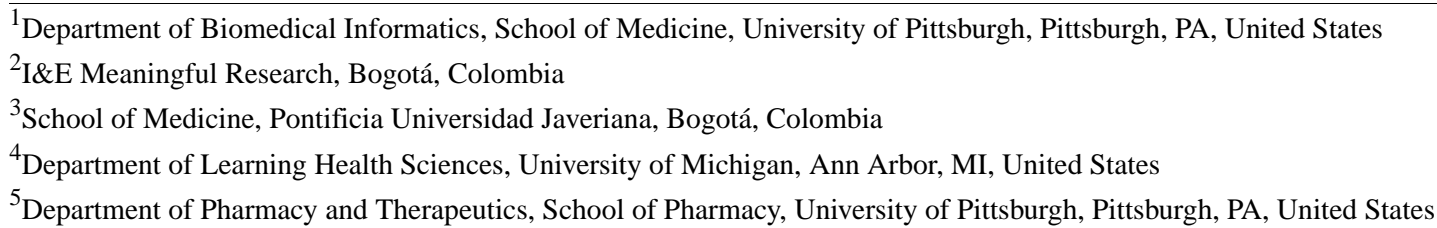

\section{Corresponding Author:}

Jhon Camacho, BEng, MSc

I\&E Meaningful Research

Calle 119a \#70-31

Bogotá, 111121

Colombia

Phone: 573156955484

Email: jicamachosanchez@gmail.com

\begin{abstract}
Background: The implementation of clinical decision support systems (CDSSs) as an intervention to foster clinical practice change is affected by many factors. Key factors include those associated with behavioral change and those associated with technology acceptance. However, the literature regarding these subjects is fragmented and originates from two traditionally separate disciplines: implementation science and technology acceptance.

Objective: Our objective is to propose an integrated framework that bridges the gap between the behavioral change and technology acceptance aspects of the implementation of CDSSs.

Methods: We employed an iterative process to map constructs from four contributing frameworks- the Theoretical Domains Framework (TDF); the Consolidated Framework for Implementation Research (CFIR); the Human, Organization, and Technology-fit framework (HOT-fit); and the Unified Theory of Acceptance and Use of Technology (UTAUT)—and the findings of 10 literature reviews, identified through a systematic review of reviews approach.

Results: The resulting framework comprises 22 domains: agreement with the decision algorithm; attitudes; behavioral regulation; beliefs about capabilities; beliefs about consequences; contingencies; demographic characteristics; effort expectancy; emotions; environmental context and resources; goals; intentions; intervention characteristics; knowledge; memory, attention, and decision processes; patient-health professional relationship; patient's preferences; performance expectancy; role and identity; skills, ability, and competence; social influences; and system quality. We demonstrate the use of the framework providing examples from two research projects.
\end{abstract}

Conclusions: We proposed BEAR (BEhavior and Acceptance fRamework), an integrated framework that bridges the gap between behavioral change and technology acceptance, thereby widening the view established by current models.

(J Med Internet Res 2020;22(8):e18388) doi: $\underline{10.2196 / 18388}$

\section{KEYWORDS}

clinical decision support system; computerized decision support system; implementation science; technology acceptance; barriers; facilitators; determinants; decision support system 


\section{Introduction}

Every year, significant amounts of resources are invested in medical research globally, an average of $0.19 \%$ of the gross domestic product in high-income countries [1]. All this effort has resulted in the exponential growth of scientific evidence. However, the translation of that knowledge into changes in clinical practice is advancing at a much lower rate, creating a growing knowledge-practice gap [2]. Reducing this gap requires not only the development and dissemination of evidence-based guidelines but also the integration of guideline recommendations into care processes and that health professionals change their practice. Clinical decision support systems (CDSSs) present a promising approach to address these challenges [3-6].

CDSSs encode clinical knowledge into computerized algorithms and combine them with patient-specific data to provide clinicians with information and decision guidance [7]. When successfully implemented, the ability of a CDSS to provide patient-specific decision support empowers health professionals to make timely decisions at the point of care while reducing medical errors $[8,9]$. Another benefit of this technology is that the transformation of clinical knowledge into algorithms allows for the correction of areas where documents (eg, clinical practice guidelines) are ambiguous or unclear [10-13]. CDSSs have been implemented to support care in several specialties [14-20], both in developed and developing countries [14,18,21].

Although several literature reviews have shown improvements in process measures after the implementation of CDSSs [8,22-24], the evidence of their effectiveness on clinical outcomes is still mixed $[22,25,26]$. This is partially explained because successful implementation of practice-change interventions is a multidimensional problem requiring attention to many factors [27-30]. Relevant factors include not only those internal and external to the health organization [29] but also those related to the clinicians' preferences and their mental model about their practice [28,30]. Additionally, CDSSs must be integrated into the clinical workflow and be accepted by the users.

We hypothesize that improving the implementation of CDSSs requires attention to factors related to practice change and also to those associated with technology acceptance, defined as the user's decision to use a technology system routinely [31]. Theories and frameworks about these topics can be found in the research fields of implementation science and technology acceptance. However, though drawing from similar sources (ie, psychology, sociology, and management science), these fields have developed into separate disciplines. Therefore, a researcher considering studying the implementation of a CDSS as a strategy to foster clinical change is confronted with a fragmented corpus of knowledge and the choice among conceptual frameworks, potentially missing or having to give up the contributions from one of these fields.

Another issue is that there are competing frameworks within the fields of implementation science and technology acceptance. Several authors have proposed theoretical models to explain the determinants of clinical practice change [32]. Similarly, several models attempt to explain the factors influencing the user's decision to use a technology system routinely [33,34]. Furthermore, several recent studies have identified determinants that are specific to the acceptance of CDSSs [35-40]. When seen together, these frameworks amount to too many concepts for a reasonable research project to use effectively.

To address these issues, we propose BEAR (BEhavior and Acceptance fRamework), an integrated conceptual framework that bridges the gap between behavioral change and technology acceptance aspects of the implementation of CDSSs. BEAR synthesizes literature about factors influencing both practice change and acceptance of CDSSs from the health professional's perspective. Furthermore, BEAR seeks to capture the variability in the phenomenon of implementing CDSSs while providing an integrated tool that facilitates the design of research and evaluation projects.

\section{Methods}

\section{Overview}

We developed BEAR by employing an iterative process in which two investigators (JC and MZM) mapped constructs reported in the literature as determinants of behavioral change and acceptance of CDSSs (see Figure 1). In each iteration, both investigators mapped the constructs from a framework or a literature review into the emerging construct pool, starting with the Theoretical Domains Framework (TDF) [28,30] and the Unified Theory of Acceptance and Use of Technology (UTAUT) [34]. At the beginning of each iteration, the two investigators (JC and MZM) developed maps independently contrasting the information in the articles with the definitions in the construct pool. After that, the investigators discussed differences in their maps and agreed on modifications to the pool. These modifications encompassed the following: the inclusion of new constructs, in addition to agreeing to their definitions; changes in construct labels or definitions; and changes in the grouping of constructs into domains. The emerging framework was progressively documented in two files: one contained the definitions and the other contained the map to the original constructs (see Multimedia Appendices 1 and 2). 
Figure 1. Framework development. TDF: Theoretical Domains Framework; UTAUT: Unified Theory of Acceptance and Use of Technology.

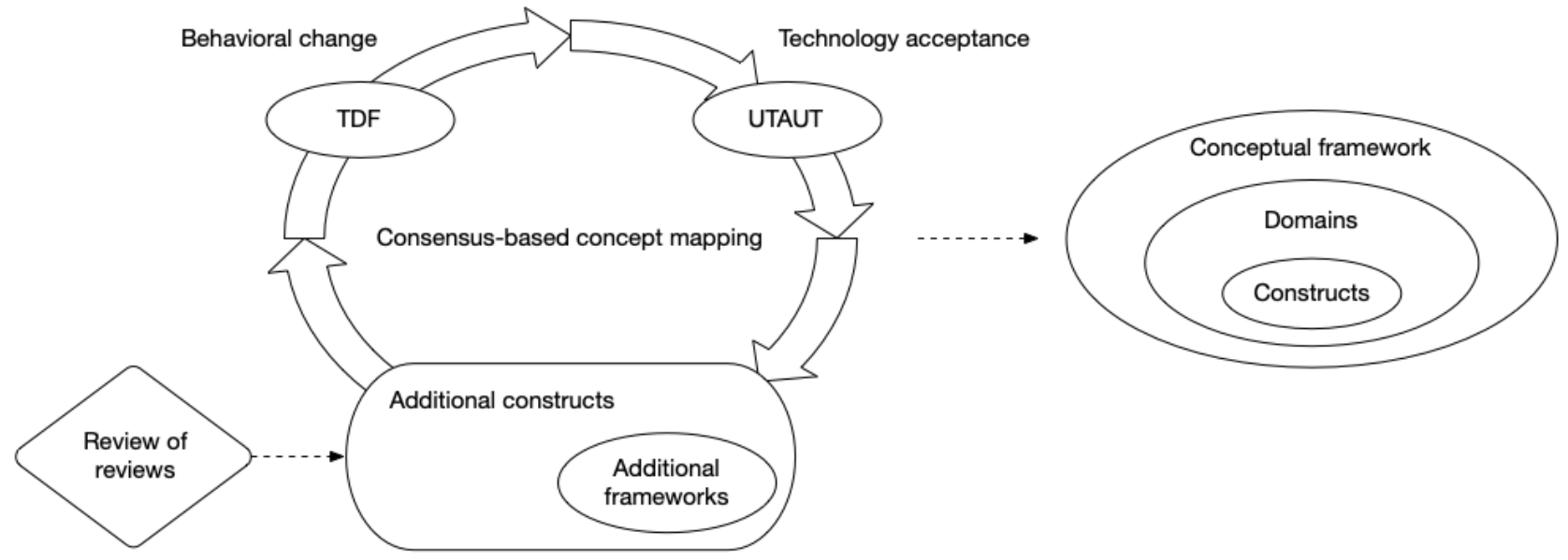

\section{Base Frameworks}

The first iteration comprised the mapping of two well-established frameworks: the TDF $[28,30]$ and the UTAUT [34]. The TDF, proposed by Michie et al in 2005 [30] and revised by Cane et al in 2012 [28], comprises 84 theoretical constructs included in classic psychological theories about behavior change. The UTAUT, on the other hand, was proposed by Venkatesh et al in 2003 [34] to integrate the eight predominant models at the time about technology acceptance. The UTAUT comprises eight constructs that influence the regular use of a technology, directly or indirectly. The selection of these frameworks as a starting point was guided by the authors' previous experiences with the evaluation of medical informatics interventions.

\section{Literature Review}

Subsequent iterations comprised the mapping of constructs identified through a literature review of recent aggregative studies presenting determinants of the acceptance of CDSSs. To obtain the initial pool of references, we queried Scopus, MEDLINE (Medical Literature Analysis and Retrieval System Online), Embase, CINAHL (Cumulative Index of Nursing and Allied Health Literature), and PsycINFO. Figure 2 presents the search strategy used in Scopus. We constructed equivalent searches for the other databases.

Figure 2. Search strategy used in Scopus.

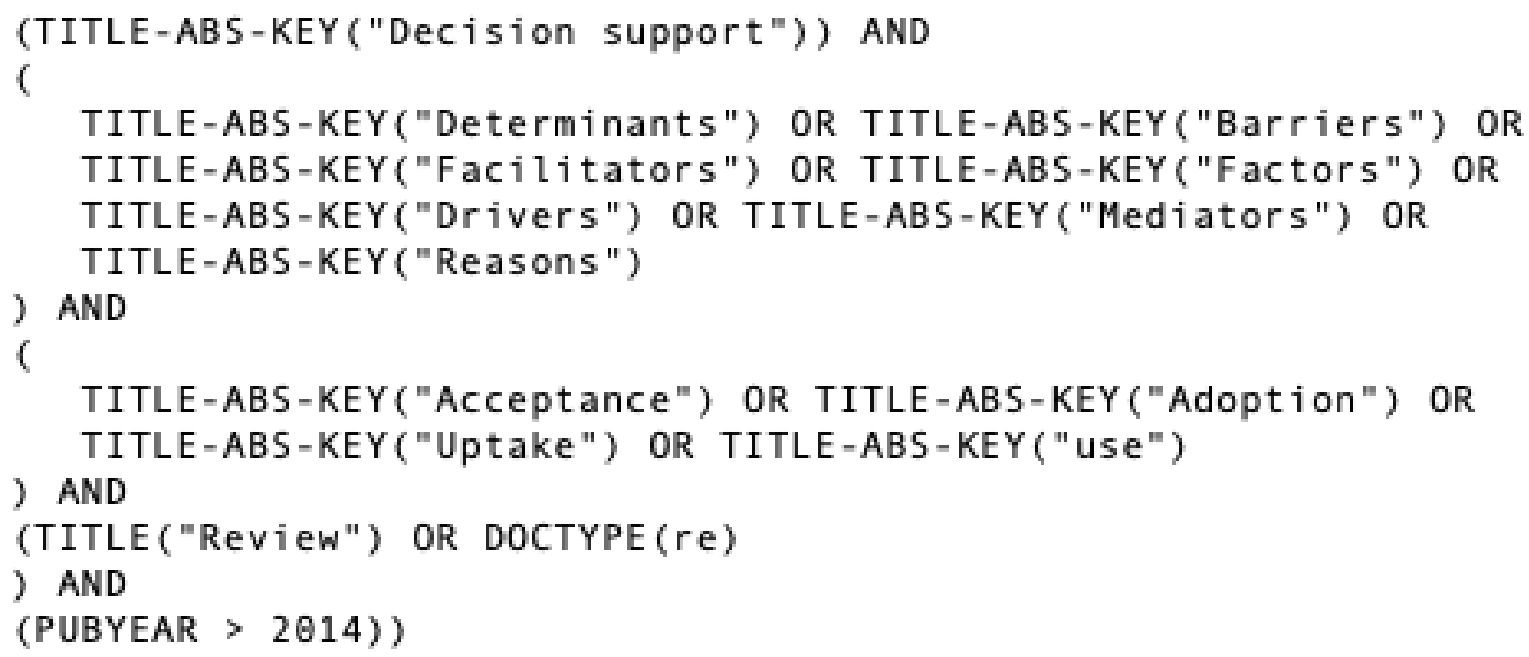

Two investigators (JC and MZM) screened the initial reference pool and evaluated their titles and abstracts. For a reference to be selected, it needed to fulfill all of the following inclusion criteria: (1) address the topic of CDSSs, (2) employ literature review methods to obtain its results, and (3) include, among its results, determinants of the acceptance of CDSSs. Exclusion criteria were limited to the following: (1) the publication was not a research article (eg, abstract, viewpoint, commentary, editorial, or protocol) and (2) the full text was not in English or Spanish.
We limited the search strategy to articles published since 2014; we were working under the assumption that, although recent, the aggregate studies found would cover the relevant literature published before that year. That assumption was validated by documenting the period covered by each included review.

The investigators (JC and MZM) then extracted the constructs and their definitions from the full text of each article (see Multimedia Appendix 1). In cases where definitions or descriptions were not explicitly stated, the investigators reviewed the full text of the cited articles, including 
supplemental materials. Furthermore, in cases where other frameworks were used to organize the review findings, those frameworks were included in the mapping exercise with their own iterations.

\section{Domain Structure and Refinement}

The grouping of constructs into domains was initially informed by the organization and definitions in the base frameworks (ie, TDF and UTAUT). Later on, new constructs identified from the literature reviews were contrasted with the domain definitions to choose their locations. In some cases, this process resulted in the creation of new domains or in changing previous definitions.

Finally, preliminary versions of the framework were discussed with the other authors (ZLL, SLKG, and RDB) and other colleagues, resulting in the refinement of construct labels, definitions, and grouping.

\section{Results}

\section{Overview}

The mapping process comprised 13 iterations, corresponding to 10 reviews and four frameworks. The initial literature search identified 584 references. After removing duplicates, 405 references passed through the screening process (see Figure 3). Of these, 23 were selected for full-text assessment; however, text from six of these articles was not available. After reviewing the 17 available articles, seven were excluded. Finally, 10 articles met all inclusion criteria [35-40,42,45]. Only one article was excluded based on language. Table 1 shows the characteristics of the reviews included in this study and any associated frameworks [29,35-45].

Figure 3. Flow diagram of the literature review. CDSS: clinical decision support system.

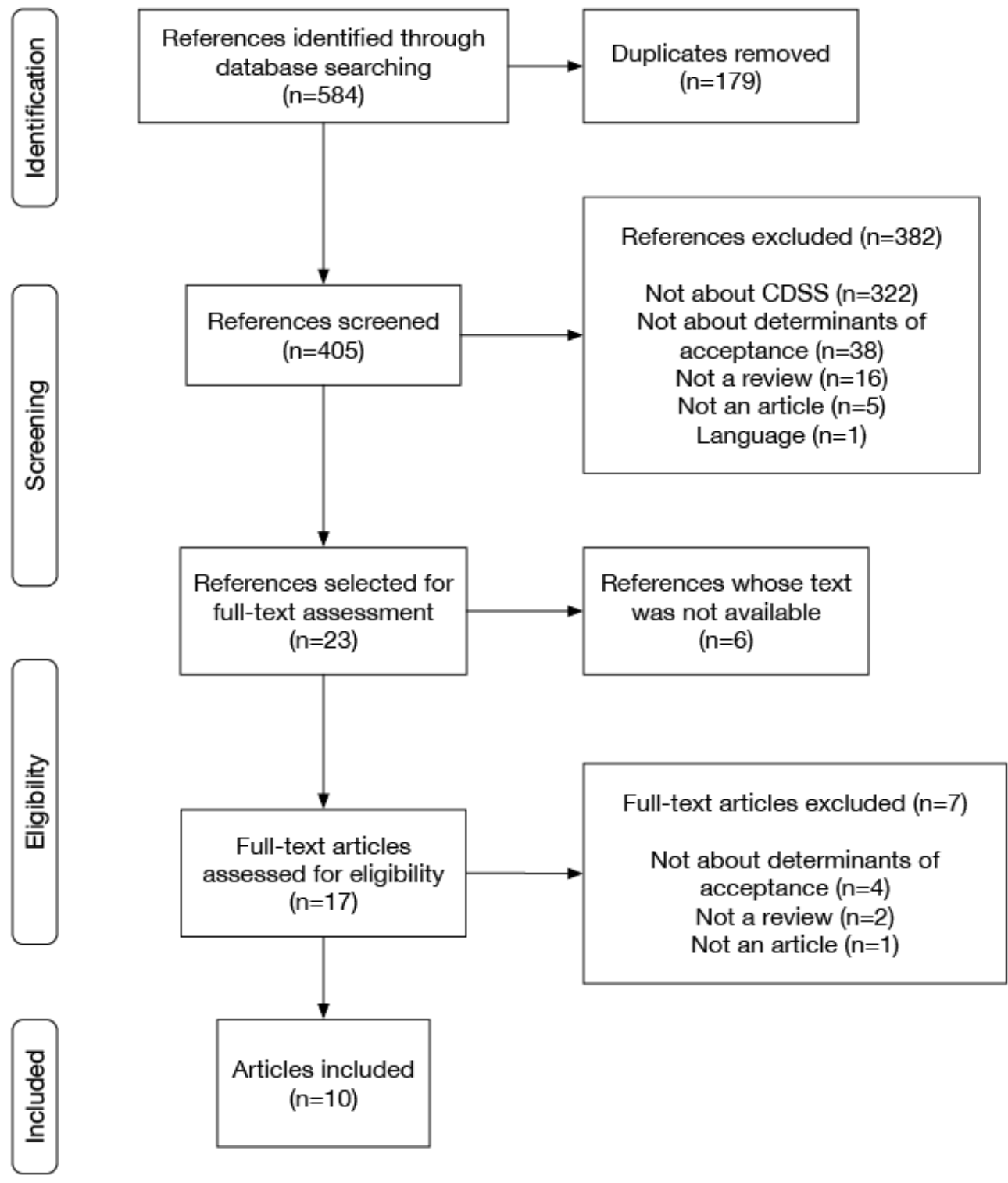

\section{Included Reviews}

The 10 reviews included in the mapping exercise (see Table 1) synthesize 219 studies from 1995 to 2018 ; these studies include participants from several populations of health professionals (ie, nurses, general practitioners, specialists, pharmacists, residents, laboratory technicians, physical therapists, medical 
assistants, medical students, paramedics, psychologists, and social workers). Additionally, two frameworks were included: the CFIR (Consolidated Framework for Implementation Research) [29], which was used in Ross et al [37], and the
HOT-fit (Human, Organization, and Technology-fit) framework [41], which was used in Kilsdonk et al [38] and Van Dort et al [44].

Table 1. Characteristics of included reviews.

\begin{tabular}{|c|c|c|c|c|}
\hline Source & Number of references & Time span & Participants & Framework \\
\hline Khong et al, 2015 [35] & 16 & 2005-2014 & $\begin{array}{l}\text { Nurses, general practitioners, specialists, pharmacists, and } \\
\text { medical assistants }\end{array}$ & $\mathrm{N} / \mathrm{A}^{\mathrm{a}}$ \\
\hline Khairat et al, 2018 [36] & 14 & $1995-2015$ & $\begin{array}{l}\text { Nurses, general practitioners, specialists, residents, and medi- } \\
\text { cal students }\end{array}$ & N/A \\
\hline Ross et al, 2016 [37] & 44 & $2002-2014$ & $\begin{array}{l}\text { Nurses, general practitioners, specialists, laboratory techni- } \\
\text { cians, physical therapists, paramedics, medical students, resi- } \\
\text { dents, pharmacists, and social workers }\end{array}$ & $\mathrm{CFIR}^{\mathrm{b}}[29]$ \\
\hline Kilsdonk et al, 2017 [38] & 35 & 2003-2015 & $\begin{array}{l}\text { Nurses, general practitioners, specialists, physical therapists, } \\
\text { medical students, residents, pharmacists, and psychologists }\end{array}$ & HOT-fit $^{\mathrm{c}}[41]$ \\
\hline Miller et al, 2017 [39] & 14 & 2003-2015 & $\begin{array}{l}\text { Nurses, general practitioners, specialists, pharmacists, medical } \\
\text { assistants, and residents }\end{array}$ & N/A \\
\hline Borum, 2018 [40] & 9 & 2011-2016 & Nurses, general practitioners, specialists, and pharmacists & N/A \\
\hline Baig et al, 2019 [42] & 22 & 2014-2016 & Nurses, general practitioners, and specialists & N/A \\
\hline Carter et al, 2019 [43] & 13 & 2014-2017 & $\begin{array}{l}\text { Nurses, midwives, nurse students, specialists, and community } \\
\text { health workers }\end{array}$ & N/A \\
\hline Van Dort et al, 2019 [44] & 13 & 2009-2018 & General practitioners and specialists & HOT-fit [41] \\
\hline Hussain et al, 2019 [45] & 39 & $2008-2017$ & Nurses, general practitioners, and specialists & N/A \\
\hline
\end{tabular}

${ }^{\mathrm{a} N}$ /A: not applicable.

${ }^{\mathrm{b}}$ CFIR: Consolidated Framework for Implementation Research.

${ }^{\mathrm{c}}$ HOT-fit: Human, Organization, and Technology-fit.

\section{BEAR}

Table 2 presents the constructs and domains included in the proposed framework [28,34,46-50]. The mapping of each

construct into the sources is included in Multimedia Appendix 2. BEAR comprises 156 constructs arranged into 22 domains. Domain definitions are included in Table 2, whereas definitions for each construct are included in Multimedia Appendix 1. 
Table 2. BEAR (BEhavior and Acceptance fRamework) constructs and domains.

\begin{tabular}{|c|c|c|}
\hline Domain $^{\mathrm{a}}$ & Domain definition & Constructs $^{b}$ \\
\hline Knowledge & $\begin{array}{l}\text { Awareness, understanding, or information about a subject } \\
\text { that has been obtained by experience or study: based on } \\
{[46]}\end{array}$ & $\begin{array}{l}\text { Knowledge } \\
\text { Knowledge of task environment } \\
\text { Procedural knowledge } \\
\text { Knowledge of the decision algorithm } \\
\text { Knowledge of the patient's condition } \\
\text { Previous experience with decision support technology }\end{array}$ \\
\hline $\begin{array}{l}\text { Skills, ability, and compe- } \\
\text { tence }\end{array}$ & $\begin{array}{l}\text { An ability or proficiency acquired through training and } \\
\text { practice [28]: based on [47] }\end{array}$ & $\begin{array}{l}\text { Skills, ability, and competence } \\
\text { Computer and mobile device skill } \\
\text { Interpersonal skills } \\
\text { Skills development }\end{array}$ \\
\hline Role and identity & $\begin{array}{l}\text { A coherent set of behaviors and displayed personal qual- } \\
\text { ities of an individual in a social or work setting [28]: based } \\
\text { on [47] }\end{array}$ & $\begin{array}{l}\text { Individual identity } \\
\text { Professional identity } \\
\text { Organizational commitment } \\
\text { Professional boundaries } \\
\text { Professional role } \\
\text { Professional autonomy }\end{array}$ \\
\hline Beliefs about capabilities & $\begin{array}{l}\text { Acceptance of the truth, reality, or validity about an abil- } \\
\text { ity, talent, or facility that a person can put to constructive } \\
\text { use [28]: based on [47] }\end{array}$ & $\begin{array}{l}\text { Beliefs about capabilities } \\
\text { Empowerment } \\
\text { Perceived behavioral control } \\
\text { Professional confidence } \\
\text { Self-confidence } \\
\text { Self-efficacy } \\
\text { Self-esteem }\end{array}$ \\
\hline $\begin{array}{l}\text { Beliefs about conse- } \\
\text { quences }\end{array}$ & $\begin{array}{l}\text { Acceptance of the truth, reality, or validity about out- } \\
\text { comes of a behavior in a given situation [28]: based on } \\
\text { [47] }\end{array}$ & $\begin{array}{l}\text { Beliefs about consequences } \\
\text { Anticipated regret } \\
\text { Outcome expectancies } \\
\text { Beliefs that technology would disrupt the delivery of care } \\
\text { Characteristics of outcome expectancies } \\
\text { Concerns about liability and responsibility } \\
\text { Concerns over patient privacy }\end{array}$ \\
\hline Attitudes & $\begin{array}{l}\text { Relatively enduring and general evaluations of an object, } \\
\text { person, group, issue, or concept on a dimension ranging } \\
\text { from negative to positive. Attitudes provide summary } \\
\text { evaluations of target objects and are often assumed to be } \\
\text { derived from specific beliefs, emotions, and past behaviors } \\
\text { associated with those objects [48]. }\end{array}$ & $\begin{array}{l}\text { Attitudes } \\
\text { Interest in technology } \\
\text { Perceived uselessness } \\
\text { Optimism } \\
\text { Pessimism } \\
\text { Unrealistic optimism } \\
\text { Attitude toward practice guidelines }\end{array}$ \\
\hline Contingencies & $\begin{array}{l}\text { A conditional probabilistic relationship between two } \\
\text { events. Contingencies may be arranged via dependencies } \\
\text { or they may emerge by accident [28]: citing [47]. }\end{array}$ & $\begin{array}{l}\text { Contingencies } \\
\text { Consequences } \\
\text { Reinforcement } \\
\text { Incentives } \\
\text { Punishment } \\
\text { Rewards } \\
\text { Sanctions }\end{array}$ \\
\hline
\end{tabular}




\begin{tabular}{|c|c|c|}
\hline Domain $^{\mathrm{a}}$ & Domain definition & Constructs $^{\mathrm{b}}$ \\
\hline Intentions & $\begin{array}{l}\text { A conscious decision to perform a behavior; a resolve to } \\
\text { act in a certain way or an impulse for purposeful action. } \\
\text { In experiments, intention is often equated with goals de- } \\
\text { fined by the task instruction [28]: citing [47]. }\end{array}$ & $\begin{array}{l}\text { Intentions } \\
\text { Stability of intentions } \\
\text { Stages of change-precontemplation } \\
\text { Stages of change-contemplation } \\
\text { Stages of change-preparation } \\
\text { Stages of change-action } \\
\text { Stages of change-maintenance }\end{array}$ \\
\hline Goals & $\begin{array}{l}\text { Mental representations of outcomes or end states that an } \\
\text { individual wants to achieve [28]: based on [47] }\end{array}$ & $\begin{array}{l}\text { Goals } \\
\text { Goals-level of control (autonomous vs controlled) } \\
\text { Goals-temporality (distal vs proximal) } \\
\text { Target setting } \\
\text { Goal priority } \\
\text { Action planning } \\
\text { Change plan }\end{array}$ \\
\hline $\begin{array}{l}\text { Memory, attention, and } \\
\text { decision processes }\end{array}$ & $\begin{array}{l}\text { The ability to retain information, focus selectively on as- } \\
\text { pects of the environment, and choose between two or } \\
\text { more alternatives [28]: based on [47] }\end{array}$ & $\begin{array}{l}\text { Memory } \\
\text { Attention } \\
\text { Attention control } \\
\text { Decision process } \\
\text { Cognitive overload and tiredness }\end{array}$ \\
\hline $\begin{array}{l}\text { Environmental context } \\
\text { and resources }\end{array}$ & $\begin{array}{l}\text { Any circumstance of a person's situation or environment } \\
\text { that discourages or encourages the development of skills } \\
\text { and abilities, independence, social competence, and } \\
\text { adaptive behavior [28]: based on [47] }\end{array}$ & $\begin{array}{l}\text { Environmental context } \\
\text { Resources } \\
\text { Environmental stressors } \\
\text { Organizational structure } \\
\text { Organizational culture and climate } \\
\text { Assessment—-skills } \\
\text { Assessment—-knowledge } \\
\text { Assessment—performance } \\
\text { Person } \times \text { environment interaction } \\
\text { Salient events and critical incidents } \\
\text { Time availability—patient care } \\
\text { Time availability—learning } \\
\text { Technical support } \\
\text { Technical infrastructure } \\
\text { Facilities } \\
\text { Implementation climate } \\
\text { Tension for change } \\
\text { Access to information and knowledge about the intervention }\end{array}$ \\
\hline Social influences & $\begin{array}{l}\text { Those interpersonal processes that can cause individuals } \\
\text { to change their thoughts, feelings, or behaviors [28]: based } \\
\text { on [47] } \\
\text { The degree to which an individual perceives that others } \\
\text { important to him or her believe he or she should use the } \\
\text { new system [34] }\end{array}$ & $\begin{array}{l}\text { Social influences } \\
\text { Alienation } \\
\text { Group conformity } \\
\text { Group identity } \\
\text { Group norms } \\
\text { Leadership } \\
\text { Intergroup conflict } \\
\text { Modelling } \\
\text { Power } \\
\text { Social comparisons } \\
\text { Social norms } \\
\text { Social pressure } \\
\text { Social support }\end{array}$ \\
\hline
\end{tabular}




\begin{tabular}{|c|c|c|}
\hline Domain $^{\mathrm{a}}$ & Domain definition & Constructs $^{\mathrm{b}}$ \\
\hline Emotions & $\begin{array}{l}\text { A complex reaction pattern, involving experiential, behav- } \\
\text { ioral, and physiological elements, by which the individual } \\
\text { attempts to deal with a personally significant matter or } \\
\text { event [28]: based on [47] }\end{array}$ & $\begin{array}{l}\text { Emotions } \\
\text { Affect } \\
\text { Positive affect } \\
\text { Negative affect } \\
\text { Anxiety } \\
\text { Burnout } \\
\text { Depression } \\
\text { Apprehension } \\
\text { Fear } \\
\text { Stress } \\
\text { Frustration } \\
\text { Uncertainty } \\
\text { Dissatisfaction }\end{array}$ \\
\hline Behavioral regulation & $\begin{array}{l}\text { Anything aimed at managing or changing objectively } \\
\text { observed or measured actions [28]: based on [47] }\end{array}$ & $\begin{array}{l}\text { Behavioral regulation } \\
\text { Breaking habit } \\
\text { Self-monitoring }\end{array}$ \\
\hline $\begin{array}{l}\text { Intervention characteris- } \\
\text { tics }\end{array}$ & $\begin{array}{l}\text { Intervention attributes that facilitate or hinder its imple- } \\
\text { mentation. The intervention includes not only the system } \\
\text { but also all processes and resources needed to deploy it. }\end{array}$ & $\begin{array}{l}\text { Intervention characteristics } \\
\text { Intervention source } \\
\text { Adaptability } \\
\text { Trialability } \\
\text { Interoperability } \\
\text { Implementation complexity } \\
\text { Costs-initial } \\
\text { Costs-recurrent } \\
\text { Voluntariness of use }\end{array}$ \\
\hline Performance expectancy & $\begin{array}{l}\text { The degree to which an individual believes that using the } \\
\text { system will help him or her to attain gains in job perfor- } \\
\text { mance [34] }\end{array}$ & $\begin{array}{l}\text { Performance expectancy } \\
\text { Benefits for the patient } \\
\text { Improved communication with other health professionals } \\
\text { Improved access to knowledge } \\
\text { Consistency of care } \\
\text { Error prevention } \\
\text { Time-saving } \\
\text { Habituation }\end{array}$ \\
\hline Effort expectancy & $\begin{array}{l}\text { The effort an individual believes is required to implement } \\
\text { or use the system }\end{array}$ & $\begin{array}{l}\text { Effort expectancy } \\
\text { Quality of the user interface } \\
\text { Compatibility with the clinical workflow } \\
\text { Access at the point of care } \\
\text { Familiarization }\end{array}$ \\
\hline $\begin{array}{l}\text { Demographic characteris- } \\
\text { tics }\end{array}$ & $\begin{array}{l}\text { The characteristics of people who form a particular group, } \\
\text { with reference to distribution, composition, or structure: } \\
\text { based on }[46,49]\end{array}$ & $\begin{array}{l}\text { Demographic characteristics } \\
\text { Age } \\
\text { Gender } \\
\text { Professional experience } \\
\text { Training level and educational level } \\
\text { Nationality }\end{array}$ \\
\hline
\end{tabular}




\begin{tabular}{|c|c|c|}
\hline Domain $^{\mathrm{a}}$ & Domain definition & Constructs ${ }^{\mathrm{b}}$ \\
\hline System quality & $\begin{array}{l}\text { The degree to which the information and functions pro- } \\
\text { vided by the system meet the user's needs or expectations } \\
\text { and give user satisfaction; the degree to which the system } \\
\text { is free from deficiencies or defects: based on [50] }\end{array}$ & $\begin{array}{l}\text { System quality } \\
\text { System performance } \\
\text { Output quality } \\
\text { Output quality—accuracy } \\
\text { Output quality—completeness } \\
\text { Output quality—specificity } \\
\text { Output quality—timeliness } \\
\text { System reliability }\end{array}$ \\
\hline $\begin{array}{l}\text { Agreement with the deci- } \\
\text { sion algorithm }\end{array}$ & $\begin{array}{l}\text { The degree to which the user agrees that the decision al- } \\
\text { gorithm is a correct way to make the intended decision }\end{array}$ & $\begin{array}{l}\text { Agreement with the decision algorithm } \\
\text { Applicability to complex cases } \\
\text { Evidence strength and quality }\end{array}$ \\
\hline $\begin{array}{l}\text { Patient-health profession- } \\
\text { al relationship }\end{array}$ & $\begin{array}{l}\text { The way the system affects the relationship between the } \\
\text { health professional and the patient }\end{array}$ & $\begin{array}{l}\text { Patient-health professional relationship } \\
\text { Obtrusiveness } \\
\text { Diminished eye contact } \\
\text { Disruption of flow in conversation with the patient } \\
\text { Knowledgeable image }\end{array}$ \\
\hline Patient's preferences & $\begin{array}{l}\text { The way the patient's preferences affect the health profes- } \\
\text { sional's decision about using the system }\end{array}$ & $\begin{array}{l}\text { Patient's preferences } \\
\text { Patient's decision not to follow the recommendation }\end{array}$ \\
\hline
\end{tabular}

${ }^{a}$ The way we include references in this column seeks to help the reader trace back the origin of each definition. In cases where we use the same text from the source (ie, a textual citation), we only include the reference number. In cases where the source text was adapted, we precede the reference number with the phrase "based on." In cases where the source is citing another source, we include a reference for the latter, preceded by the word "citing." Finally, definitions without a reference were developed by the authors.

${ }^{\mathrm{b}}$ Construct definitions are included in Multimedia Appendix 1.

\section{Discussion}

\section{Principal Findings}

Our objective was to develop a framework, grounded in the literature about determinants of behavioral change and technology acceptance, that would be useful to researchers investigating the implementation of CDSSs as a strategy to foster the uptake of evidence-based recommendations.

\section{Developing Strategy and Structure}

The idea of BEAR originated in our search for a conceptual framework to guide our research in the use of CDSSs as a strategy to implement clinical practice guidelines. From the beginning, we realized that the effectiveness of such an approach would be mediated by aspects of behavioral change and technology acceptance. We found part of the guidance we were looking for in the TDF [28,30] and the UTAUT [34]. These frameworks provide constructs that address both aspects of the phenomenon, although at a higher level than the one we were seeking, particularly on the side of technology acceptance. For example, UTAUT includes the concept of facilitating conditions, defined as "the degree to which an individual believes that an organizational and technical infrastructure exists to support the use of the system" [34]. However, that definition is not enough to identify what specific facilitating conditions are missing, which we consider a necessary step for the development of interventions. This need for further detail is what led us to an iterative process by which we incorporated the findings of recent literature reviews about determinants of the acceptance of CDSSs.
To capture the variability in the phenomenon of implementing CDSSs, we sought to include constructs that are specific enough to facilitate the identification of what is different between one implementation experience and another. For example, we added constructs to represent four quality aspects for the system's output: accuracy, completeness, specificity, and timeliness. However, recognizing that it is unlikely that we have identified every relevant concept, we also included general constructs, in this case output quality. Along the same lines, most domains include a construct that shares the domain's label. In cases where a domain label corresponds to a group of concepts (eg, memory, attention, and decision processes), we do not include a general construct but only those representing each constituting concept.

The decision to include both specific and general constructs led us to make two more decisions about the framework's structure: (1) to have only one grouping level (ie, domain and construct) and (2) to include each construct only once, inside the domain where, in our opinion, the construct fits better. With these decisions, we sought to control complexity while maintaining detail. The resulting domains sort the constructs thematically; that is, constructs included in a domain represent determinants that could influence the concept represented by the domain, instead of particularizations of that concept.

\section{Use Cases}

BEAR is not a parsimonious framework. We believe this is both a strength and a limitation. On the one hand, we expect that the level of detail facilitates the identification of actionable determinants; on the other hand, using the whole framework could be difficult, particularly in quantitative-oriented projects. 
However, for most projects, using every construct in the framework is not necessary or even advisable.

Our recommendation is to use the framework at the domain level during the initial stages of research design, particularly when discussing scope. Later, in qualitative-oriented studies, BEAR could be utilized to develop data collection guides for interviews, focus groups, or observations. This could be done at the domain level, in the case of exploratory studies, or based on selected constructs. During analysis, BEAR could serve as an initial coding schema, either at the domain or construct levels, raising the researcher's awareness of determinants and supporting the identification of categories.

In quantitative-oriented studies, besides informing decisions about scope and research questions, BEAR could support the search for theories and measurement tools. In both cases, we recommend reviewing the definitions and references provided in Multimedia Appendix 1.

In the next section, we present two examples of how we have used BEAR in our research.

\section{Use Example: A CDSS to Support Chronic Obstructive Pulmonary Disease Active Case-Finding}

We are currently using BEAR in a qualitative-oriented project whose objective is to identify barriers and facilitators to the use of a CDSS to support the implementation of a case-finding recommendation included in the Colombian chronic obstructive pulmonary disease (COPD) clinical practice guideline.

According to the recommendation, suspicion of airflow obstruction could be established by the identification of specific risk factors and symptoms. Once the suspicion is established, spirometry should be ordered to confirm the limitation in the airflow [51].

In the study, we explained the recommendation to primary-level physicians and asked them to use a CDSS, implemented as a mobile app, during their patient encounters. The CDSS asked a series of questions about the patient's clinical history and current symptoms. Using this information, the system applied a decision algorithm to establish the suspicion of COPD, in which case it recommended that the participant order a spirometry test to discard or confirm the diagnosis.

After 2 months using the system, we interviewed the participants to explore their experiences applying the recommendation and using the system. The guide used in these interviews was developed using BEAR at the domain level. Table 3 presents selected questions included in the guide. Designing the interview around BEAR's domains allowed us to explore both the behavioral change and the technology acceptance aspects of the intervention.

Table 3. Example 1 questions.

\begin{tabular}{|c|c|}
\hline Domain & Questions \\
\hline \multirow[t]{2}{*}{ Knowledge } & Before this project, did you know about this recommendation? \\
\hline & $\begin{array}{l}\text { Given the information you had before, and what we have given you in the project, do you consider that you } \\
\text { have all the information you need to carry out the screening? }\end{array}$ \\
\hline Role and identity & $\begin{array}{l}\text { Do you consider that screening for COPD }{ }^{\mathrm{a}} \text { cases is part of the primary care physician's responsibility or } \\
\text { should it be assigned to someone else? }\end{array}$ \\
\hline \multirow[t]{2}{*}{ Performance expectancy } & Was the app useful in the process of implementing the recommendation? \\
\hline & How did you use it? \\
\hline Agreement with the decision algorithm & $\begin{array}{l}\text { Can you think of anything that the ministry could change in the content of the recommendation to make it } \\
\text { easier to meet the goal of detecting COPD cases early? }\end{array}$ \\
\hline
\end{tabular}

${ }^{\mathrm{a}}$ COPD: chronic obstructive pulmonary disease.

Data collected in the interviews were analyzed thematically using BEAR's constructs as the initial coding schema. During the initial analysis, the transcript below-adapted from the original data in Spanish-was coded under the following constructs: patient-health professional relationship, diminished eye-contact, and patient's preferences.

...nowadays, we hardly see the patient, we are always [gestures representing the use of a keyboard]. We are all the time writing in the health record...In fact, some patients get upset. They complain that I do not look them in the eye. I try to look at them while writing in the computer, but I don't have the ability yet. [Participant]

Does this mean that they got upset when you used the application on your phone? [Interviewer]

\section{No, because I tell them, "Look, I am going to use this app to help in the diagnosis," and I show them my phone. [Participant]}

Later in the analysis, the review of the content in these codes led to development of two categories: perceived loss of attention and negotiating the use of the device with the patient. The first category refers to the way the patient seems to interpret and resent that he has lost the physician's attention when the latter is using the computer. The second category refers to the way physicians prevent complaints about themselves when using the phone during the encounter by telling the patients what they are using the phone for and sometimes including them in the process of using the system. The relationship between these categories allows us to recognize differential effects over the patient-health professional relationship of CDSSs implemented as mobile apps and as desktop applications. 


\section{Use Example: Clinician Responsiveness to the CDSS in Clinical Practice}

Alert fatigue is a common problem for clinicians who use technology designed to improve patient safety. Evidence-based strategies to overcome alert fatigue are lacking, especially in the intensive care unit (ICU). There is an evidence gap, as discussed in a recent review and guidance document [52].

The goal of the project in this use example is to provide effective strategies for the management of alert fatigue in the ICU. The behavioral change of interest is increasing clinician responsiveness to CDSS alerts provided during patient care (eg, ordering medications). Formative research needs to be completed to understand the barriers and facilitators to clinicians' responsiveness to alerts. To meet these goals, a mixed methods approach was applied using a survey and in-depth interviews conducted with critical care clinicians. Questions were developed based on BEAR at the domain level. A sample of selected questions is provided in Table 4.

Table 4. Example 2 questions.

\begin{tabular}{ll}
\hline Domain & Questions \\
\hline Skills, ability, and competence & Do you feel competent to respond to the alerts you are receiving? \\
Beliefs about consequences & What do you think will happen if you do not respond to alerts? \\
Social influences & How responsive are your peers to alerts? \\
Emotions & How frequently does receiving an alert lead to an evoked emotional response? \\
Behavioral regulation & What would encourage you to be more responsive to alerts? \\
Performance expectancy & To what extent are the alerts useful? \\
Effort expectancy & How easy is it to respond to the alerts? \\
\hline
\end{tabular}

\section{BEAR in Relation to Other Frameworks}

Out of 122 constructs identified in the literature review, 52 (42.6\%) mapped to the TDF (see Multimedia Appendix 2). This supports our initial assumption that, in the context of CDSSs, behavioral change and technology acceptance are interrelated. Since the TDF was selected as a source from the beginning, it is not a surprise that both its constructs and structure had a substantial influence on the resulting framework. However, the TDF's constructs emerged from the mapping process with some modifications. In some cases, these changes corresponded to the integration of constructs (eg, the TDF's skills, ability, and competence, whose definitions in the American Psychological Association Dictionary of Psychology [48] are similar). In other cases, we changed the construct definition to facilitate its interpretation in the context of clinical practice change. For instance, the TDF's definition for modelling- "In developmental psychology the process in which one or more individuals or other entities serve as examples (models) that a child will copy" [28] — was changed to "The process in which one or more individuals or other entities serve as examples (models) for a person to copy." We believe these alterations do not substantially change the meaning of the affected TDF constructs, but rather improve their applicability.

The CFIR [29] and HOT-fit framework [41] were also part of the mapping process. However, several of their constructs were not included in the resulting framework due to differences in the scope. Whereas BEAR deals with behavioral change and technology acceptance from the individual's perspective, the CFIR considers the implementation as a whole, integrating other perspectives (ie, those related to the organization, the government and health system, and the implementation project [29]). In some cases, those perspectives intersected. For example, the CFIR's inner setting-implementation climate construct represents an organizational characteristic that influences the individual's behavior. However, in other cases (eg, the CFIR's process-reflecting and evaluating construct), we did not identify a direct influence over the individual. The same happened with the HOT-fit framework's organization domain [41]. We recognize that the level of influence of a particular construct over the individual's behavior could be a matter of debate-indeed, we had several discussions about it during the mapping process - thus, we used our better judgment. For information about the mapping of specific constructs, we refer the reader to Multimedia Appendix 2.

This is certainly not the first attempt to apply technology acceptance models in health care [31,53]. The majority of these attempts have tried to adapt the Technology Acceptance Model (TAM) [33], one of UTAUT's eight contributing frameworks [34]. BEAR has similarities and differences with these works. On the one hand, BEAR attempts to cover a wide range of possible determinants, but it does not make statements about the magnitude of their influence on each other or the individual's behavior. In other words, BEAR does not attempt to state a theory about technology acceptance. Instead, BEAR is meant as an exploratory tool that allows for the identification of determinants that could be articulated into hypotheses and potentially form the basis of interventions. We hope that the study of those hypotheses in different health care contexts results in a future theory that is able to explain and predict practice change in the context of CDSSs.

On the other hand, literature reviews have found that the TAM has low explanatory power in health care environments $[31,53]$. The authors of these studies attribute this lack of fit to professional differences between health professionals and other workers [53] and to the fact that the TAM does not completely incorporate the emotional and cultural aspects of health care decision making [31]. Our interpretation of these findings is that behavioral change determinants operate differently in health care in comparison to other work environments. If that is correct, 
it could be expected that bridging the gap between behavioral change and technology acceptance brings forward the missing pieces in the puzzle.

Finally, our objective of this study was to develop a conceptual framework, not a theory. A theory serves as an explanation of a phenomenon that in many cases allows for the prediction of outcomes. However, our objective was not to predict an outcome or the relative weight of each determinant in the explanation of an outcome, but to synthesize and organize all potential determinants reported in the reviewed literature. That is why we do not state any conclusion about the relationship between specific constructs, besides grouping them into domains to facilitate organization and presentation, nor their relative contribution to the success in the implementation of CDSSs. In this sense, BEAR is akin to other determinant frameworks [54], such as the TDF [28,30] or the CFIR [29], rather than a theory, such as the UTAUT [34].

\section{Acknowledgments}

This research was funded in part by the US National Institute on Aging (K01AG044433). We thank Socorro Moreno, Ps, MSc, and María Fernanda Parra, Ps, for their comments and insights regarding preliminary versions of the framework.

\section{Conflicts of Interest}

None declared.

\section{Multimedia Appendix 1}

Definitions of constructs in BEAR (BEhavior and Acceptance fRamework).

[DOC File, 224 KB-Multimedia Appendix 1]

\section{Multimedia Appendix 2}

Mapping of constructs in BEAR (BEhavior and Acceptance fRamework).

[XLS File (Microsoft Excel File), 379 KB-Multimedia Appendix 2]

\section{References}

1. Gross domestic R\&D expenditure on health (health GERD) as a \% of gross domestic product (GDP). World Health Organization. 2020 Jan. URL: https://www.who.int/research-observatory/indicators/gerd gdp/en/ [accessed 2019-11-05]

2. Morris ZS, Wooding S, Grant J. The answer is 17 years, what is the question: Understanding time lags in translational research. J R Soc Med 2011 Dec;104(12):510-520 [FREE Full text] [doi: 10.1258/jrsm.2011.110180] [Medline: 22179294]

3. Pearson S, Moxey A, Robertson J, Hains I, Williamson M, Reeve J, et al. Do computerised clinical decision support systems for prescribing change practice? A systematic review of the literature (1990-2007). BMC Health Serv Res 2009 Aug 28;9:154 [FREE Full text] [doi: 10.1186/1472-6963-9-154] [Medline: 19715591]

4. Garg AX, Adhikari NK, McDonald H, Rosas-Arellano MP, Devereaux PJ, Beyene J, et al. Effects of computerized clinical decision support systems on practitioner performance and patient outcomes: A systematic review. JAMA 2005 Mar 09;293(10):1223-1238. [doi: 10.1001/jama.293.10.1223] [Medline: 15755945$]$

5. Murphy EV. Clinical decision support: Effectiveness in improving quality processes and clinical outcomes and factors that may influence success. Yale J Biol Med 2014 Jun;87(2):187-197 [FREE Full text] [Medline: 24910564]

6. Holroyd BR, Bullard MJ, Graham TA, Rowe BH. Decision support technology in knowledge translation. Acad Emerg Med 2007 Nov;14(11):942-948 [FREE Full text] [doi: 10.1197/j.aem.2007.06.023] [Medline: 17766733]

7. Eberhardt J, Bilchik A, Stojadinovic A. Clinical decision support systems: Potential with pitfalls. J Surg Oncol 2012 Apr 01;105(5):502-510. [doi: 10.1002/jso.23053] [Medline: 22441903]

8. Kawamoto K, Houlihan CA, Balas EA, Lobach DF. Improving clinical practice using clinical decision support systems: A systematic review of trials to identify features critical to success. BMJ 2005 Apr 02;330(7494):765 [FREE Full text] [doi: 10.1136/bmj.38398.500764.8F] [Medline: 15767266 ]

9. Reis WC, Bonetti AF, Bottacin WE, Reis AS, Souza TT, Pontarolo R, et al. Impact on process results of clinical decision support systems (CDSSs) applied to medication use: Overview of systematic reviews. Pharm Pract (Granada) 2017;15(4):1036 [FREE Full text] [doi: 10.18549/PharmPract.2017.04.1036] [Medline: 29317919]

10. Codish S, Shiffman R. A model of ambiguity and vagueness in clinical practice guideline recommendations. In: Proceedings of the American Medical Informatics Association (AMIA) Annual Symposium. 2005 Presented at: American Medical Informatics Association (AMIA) Annual Symposium; October 22-26, 2005; Washington, DC p. 146-150.

11. Lee PY, Liew SM, Abdullah A, Abdullah N, Ng CJ, Hanafi NS, et al. Healthcare professionals' and policy makers' views on implementing a clinical practice guideline of hypertension management: A qualitative study. PLoS One 2015;10(5):e0126191 [FREE Full text] [doi: 10.1371/journal.pone.0126191] [Medline: 25942686] 
12. Solà I, Carrasco JM, Díaz Del Campo P, Gracia J, Orrego C, Martínez F, et al. Attitudes and perceptions about clinical guidelines: A qualitative study with Spanish physicians. PLoS One 2014;9(2):e86065 [FREE Full text] [doi: 10.1371/journal.pone.0086065] [Medline: 24505253]

13. Peleg M, González-Ferrer A. Guidelines and workflow models. In: Greenes RA, editor. Clinical Decision Support: The Road to Broad Adoption. 2nd edition. London, UK: Academic Press; 2014:435-464.

14. Blank A, Prytherch H, Kaltschmidt J, Krings A, Sukums F, Mensah N, et al. "Quality of prenatal and maternal care: Bridging the know-do gap" (QUALMAT study): An electronic clinical decision support system for rural Sub-Saharan Africa. BMC Med Inform Decis Mak 2013 Apr 10;13:44 [FREE Full text] [doi: 10.1186/1472-6947-13-44] [Medline: 23574764]

15. Moja L, Kwag KH, Lytras T, Bertizzolo L, Brandt L, Pecoraro V, et al. Effectiveness of computerized decision support systems linked to electronic health records: A systematic review and meta-analysis. Am J Public Health 2014 Dec;104(12):e12-e22. [doi: 10.2105/AJPH.2014.302164] [Medline: 25322302]

16. Cox JL, Parkash R, Abidi SS, Thabane L, Xie F, MacKillop J, IMPACT-AF Investigators. Optimizing primary care management of atrial fibrillation: The rationale and methods of the Integrated Management Program Advancing Community Treatment of Atrial Fibrillation (IMPACT-AF) study. Am Heart J 2018 Jul;201:149-157 [FREE Full text] [doi: 10.1016/j.ahj.2018.04.008] [Medline: 29807323]

17. Vecchio N, Belardi D, Benzadón M, Seoane L, Daquarti G, Scazzuso F. Impact of a hybrid decision support system to improve the adherence to implantable cardioverter defibrillator therapy guidelines for primary prevention of sudden cardiac death. Int J Med Inform 2018 Jun;114:76-80. [doi: 10.1016/j.ijmedinf.2018.03.016] [Medline: 29673607]

18. Shao AF, Rambaud-Althaus C, Samaka J, Faustine AF, Perri-Moore S, Swai N, et al. New algorithm for managing childhood illness using mobile technology (ALMANACH): A controlled non-inferiority study on clinical outcome and antibiotic use in Tanzania. PLoS One 2015;10(7):e0132316 [FREE Full text] [doi: 10.1371/journal.pone.0132316] [Medline: 26161535]

19. Dehghani Soufi M, Samad-Soltani T, Shams Vahdati S, Rezaei-Hachesu P. Decision support system for triage management: A hybrid approach using rule-based reasoning and fuzzy logic. Int J Med Inform 2018 Jun;114:35-44. [doi: 10.1016/j.ijmedinf.2018.03.008] [Medline: 29673601]

20. Martínez-Pérez B, de la Torre-Díez I, López-Coronado M, Sainz-de-Abajo B, Robles M, García-Gómez JM. Mobile clinical decision support systems and applications: A literature and commercial review. J Med Syst 2014 Jan;38(1):4. [doi: 10.1007/s10916-013-0004-y] [Medline: 24399281]

21. O'Reilly-Shah VN, Kitzman J, Jabaley CS, Lynde GC. Evidence for increased use of the Society of Pediatric Anesthesia Critical Events Checklist in resource-limited environments: A retrospective observational study of app data. Paediatr Anaesth 2018 Feb;28(2):167-173. [doi: 10.1111/pan.13305] [Medline: 29285834]

22. Souza NM, Sebaldt RJ, Mackay JA, Prorok JC, Weise-Kelly L, Navarro T, CCDSS Systematic Review Team. Computerized clinical decision support systems for primary preventive care: A decision-maker-researcher partnership systematic review of effects on process of care and patient outcomes. Implement Sci 2011 Aug 03;6:87 [FREE Full text] [doi:

10.1186/1748-5908-6-87] [Medline: 21824381]

23. Mickan S, Atherton H, Roberts NW, Heneghan C, Tilson JK. Use of handheld computers in clinical practice: A systematic review. BMC Med Inform Decis Mak 2014 Jul 06;14:56 [FREE Full text] [doi: 10.1186/1472-6947-14-56] [Medline: 24998515]

24. Free C, Phillips G, Watson L, Galli L, Felix L, Edwards P, et al. The effectiveness of mobile-health technologies to improve health care service delivery processes: A systematic review and meta-analysis. PLoS Med 2013;10(1):e1001363 [FREE Full text] [doi: 10.1371/journal.pmed.1001363] [Medline: 23458994]

25. Chan WV, Pearson TA, Bennett GC, Cushman WC, Gaziano TA, Gorman PN, et al. ACC/AHA special report: Clinical practice guideline implementation strategies: A summary of systematic reviews by the NHLBI Implementation Science Work Group: A report of the American College of Cardiology/American Heart Association task force on clinical practice guidelines. Circulation 2017 Feb 28;135(9):e122-e137. [doi: 10.1161/CIR.0000000000000481] [Medline: 28126839]

26. Gagnon M, Ngangue P, Payne-Gagnon J, Desmartis M. mHealth adoption by health care professionals: A systematic review. J Am Med Inform Assoc 2016 Jan;23(1):212-220. [doi: 10.1093/jamia/ocv052] [Medline: 26078410]

27. Lau R, Stevenson F, Ong BN, Dziedzic K, Treweek S, Eldridge S, et al. Achieving change in primary care--causes of the evidence to practice gap: Systematic reviews of reviews. Implement Sci 2016 Mar 22;11:40 [FREE Full text] [doi: 10.1186/s13012-016-0396-4] [Medline: 27001107]

28. Cane J, O'Connor D, Michie S. Validation of the theoretical domains framework for use in behaviour change and implementation research. Implement Sci 2012 Apr 24;7:37 [FREE Full text] [doi: 10.1186/1748-5908-7-37] [Medline: 22530986]

29. Damschroder LJ, Aron DC, Keith RE, Kirsh SR, Alexander JA, Lowery JC. Fostering implementation of health services research findings into practice: A consolidated framework for advancing implementation science. Implement Sci 2009 Aug 07;4:50 [FREE Full text] [doi: 10.1186/1748-5908-4-50] [Medline: 19664226]

30. Michie S, Johnston M, Abraham C, Lawton R, Parker D, Walker A. Making psychological theory useful for implementing evidence based practice: A consensus approach. Qual Saf Health Care 2005 Feb;14(1):26-33 [FREE Full text] [doi: 10.1136/qshc. 2004.011155] [Medline: 15692000 ] 
31. Ward R. The application of technology acceptance and diffusion of innovation models in healthcare informatics. Health Policy Technol 2013 Dec;2(4):222-228. [doi: 10.1016/j.hlpt.2013.07.002]

32. Tabak RG, Khoong EC, Chambers DA, Brownson RC. Bridging research and practice: Models for dissemination and implementation research. Am J Prev Med 2012 Sep;43(3):337-350 [FREE Full text] [doi: 10.1016/j.amepre.2012.05.024] [Medline: 22898128]

33. Davis FD, Bagozzi RP, Warshaw PR. User acceptance of computer technology: A comparison of two theoretical models. Manage Sci 1989 Aug;35(8):982-1003. [doi: 10.1287/mnsc.35.8.982]

34. Venkatesh V, Morris MG, Davis GB, Davis FD. User acceptance of information technology: Toward a unified view. MIS Q 2003;27(3):425. [doi: $10.2307 / 30036540]$

35. Khong PCB, Holroyd E, Wang W. A critical review of the theoretical frameworks and the conceptual factors in the adoption of clinical decision support systems. Comput Inform Nurs 2015 Dec;33(12):555-570. [doi: 10.1097/CIN.0000000000000196] [Medline: 26535769]

36. Khairat S, Marc D, Crosby W, Al Sanousi A. Reasons for physicians not adopting clinical decision support systems: Critical analysis. JMIR Med Inform 2018 Apr 18;6(2):e24 [FREE Full text] [doi: 10.2196/medinform.8912] [Medline: 29669706]

37. Ross J, Stevenson F, Lau R, Murray E. Factors that influence the implementation of eHealth: A systematic review of systematic reviews (an update). Implement Sci 2016 Oct 26;11(1):146 [FREE Full text] [doi: 10.1186/s13012-016-0510-7] [Medline: 27782832]

38. Kilsdonk E, Peute L, Jaspers M. Factors influencing implementation success of guideline-based clinical decision support systems: A systematic review and gaps analysis. Int J Med Inform 2017 Feb;98:56-64. [doi: 10.1016/j.ijmedinf.2016.12.001] [Medline: 28034413]

39. Miller K, Mosby D, Capan M, Kowalski R, Ratwani R, Noaiseh Y, et al. Interface, information, interaction: A narrative review of design and functional requirements for clinical decision support. J Am Med Inform Assoc 2018 May 01;25(5):585-592 [FREE Full text] [doi: 10.1093/jamia/ocx118] [Medline: 29126196]

40. Borum C. Barriers for hospital-based nurse practitioners utilizing clinical decision support systems: A systematic review. Comput Inform Nurs 2018 Apr;36(4):177-182. [doi: 10.1097/CIN.0000000000000413] [Medline: 29360699]

41. Yusof MM, Kuljis J, Papazafeiropoulou A, Stergioulas LK. An evaluation framework for health information systems: Human, organization and technology-fit factors (HOT-fit). Int J Med Inform 2008 Jun;77(6):386-398. [doi: 10.1016/j.ijmedinf.2007.08.011] [Medline: 17964851]

42. Baig MM, GholamHosseini H, Moqeem AA, Mirza F, Lindén M. Clinical decision support systems in hospital care using ubiquitous devices: Current issues and challenges. Health Informatics J 2019 Sep;25(3):1091-1104. [doi: 10.1177/1460458217740722] [Medline: 29148314]

43. Carter J, Sandall J, Shennan AH, Tribe RM. Mobile phone apps for clinical decision support in pregnancy: A scoping review. BMC Med Inform Decis Mak 2019 Nov 12;19(1):219 [FREE Full text] [doi: 10.1186/s12911-019-0954-1] [Medline: 31718627]

44. Van Dort BA, Zheng WY, Baysari MT. Prescriber perceptions of medication-related computerized decision support systems in hospitals: A synthesis of qualitative research. Int J Med Inform 2019 Sep;129:285-295. [doi: 10.1016/j.ijmedinf.2019.06.024] [Medline: 31445268]

45. Hussain M, Reynolds T, Zheng K. Medication safety alert fatigue may be reduced via interaction design and clinical role tailoring: A systematic review. J Am Med Inform Assoc 2019 Oct 01;26(10):1141-1149 [FREE Full text] [doi:

10.1093/jamia/ocz095] [Medline: 31206159]

46. Cambridge Dictionary. URL: https://dictionary.cambridge.org/ [accessed 2019-04-26]

47. VandenBos GR, editor. APA Dictionary of Psychology. Washington, DC: American Psychological Association; 2007.

48. APA Dictionary of Psychology. Washington, DC: American Psychological Association URL: https://dictionary.apa.org/ [accessed 2019-04-23]

49. Medical Subject Headings. National Library of Medicine. URL: https://www.nlm.nih.gov/mesh/meshhome.html [accessed 2019-04-27]

50. Akrani G. What is product quality? Definition. Meaning. Importance. Kalyan City Life Blog. 2013 May 21. URL: https:/ /kalyan-city.blogspot.com/2013/05/what-is-product-quality-definition.html [accessed 2019-04-29]

51. Londoño D, García O, Celis C, Giraldo M, Casas A, Torres C, et al. Guía de práctica clínica basada en la evidencia para la prevención, diagnóstico, tratamiento y seguimiento de la enfermedad pulmonar obstructiva crónica (EPOC) en población adulta. Acta Médica Colombiana. Volume 39 No 2 (Supl 3). 2014. URL: http://www.actamedicacolombiana.com/anexo/ articulos/2014/02S3-2014-00.pdf [accessed 2020-05-22]

52. Kane-Gill SL, O'Connor MF, Rothschild JM, Selby NM, McLean B, Bonafide CP, et al. Technologic distractions (Part 1): Summary of approaches to manage alert quantity with intent to reduce alert fatigue and suggestions for alert fatigue metrics. Crit Care Med 2017 Sep;45(9):1481-1488. [doi: 10.1097/CCM.0000000000002580] [Medline: 28682835]

53. Holden RJ, Karsh B. The technology acceptance model: Its past and its future in health care. J Biomed Inform 2010 Feb;43(1):159-172 [FREE Full text] [doi: 10.1016/j.jbi.2009.07.002] [Medline: 19615467]

54. Nilsen P. Making sense of implementation theories, models and frameworks. Implement Sci 2015 Apr 21;10:53 [FREE Full text] [doi: 10.1186/s13012-015-0242-0] [Medline: 25895742] 

Abbreviations
BEAR: BEhavior and Acceptance fRamework
CDSS: clinical decision support system
CFIR: Consolidated Framework for Implementation Research
CINAHL: Cumulative Index of Nursing and Allied Health Literature
COPD: chronic obstructive pulmonary disease
HOT-fit: Human, Organization, and Technology-fit
ICU: intensive care unit
MEDLINE: Medical Literature Analysis and Retrieval System Online
TAM: Technology Acceptance Model
TDF: Theoretical Domains Framework
UTAUT: Unified Theory of Acceptance and Use of Technology

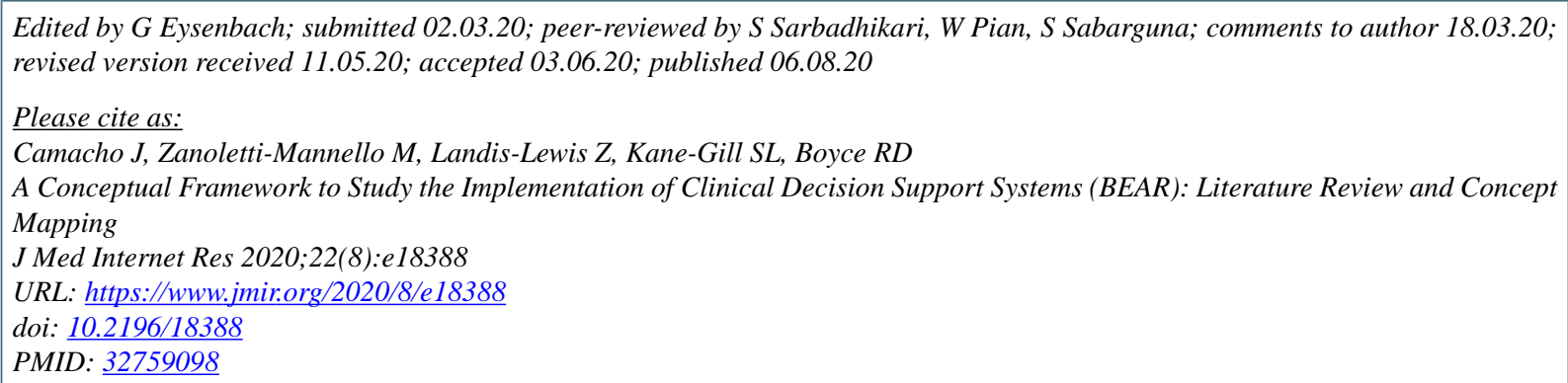

CJhon Camacho, Manuela Zanoletti-Mannello, Zach Landis-Lewis, Sandra L Kane-Gill, Richard D Boyce. Originally published in the Journal of Medical Internet Research (http://www.jmir.org), 06.08.2020. This is an open-access article distributed under the terms of the Creative Commons Attribution License (https://creativecommons.org/licenses/by/4.0/), which permits unrestricted use, distribution, and reproduction in any medium, provided the original work, first published in the Journal of Medical Internet Research, is properly cited. The complete bibliographic information, a link to the original publication on http://www.jmir.org/, as well as this copyright and license information must be included. 